\section{Evaluation of the relationships among demographic factors, pain levels, dental anxiety and coping methods in adult dental patients}

\section{Erişkin hastalarda ağrı ile başa çıkma yöntemi tercihinin demografik faktörler, ağrı düzzeyi ve dental anksiyete ile ilişkilerin değerlendirilmesi}

Kaan Hamurcu, DDS, PhD.

Gazi University, Department of Oral and

Maxillofacial Surgery, Ankara - Turkey

Orcid ID: 0000-0002-1070-0460

Sercan Küçükkurt, DDS, PhD.

Istanbul Aydın University, Department of Oral and Maxillofacial Surgery, Istanbul - Turkey

Orcid ID: 0000-0002-4095-957X

Mehmet Barıs Simșek, DDS, PhD.

Gazi University, Department of Oral and

Maxillofacial Surgery, Ankara - Turkey

Orcid ID: 0000-0002-8479-6709

Received: 15 January 2018

Accepted: 27 March 2018

doi: 10.5505/yeditepe.2019.21939

Corresponding author:

Kaan HAMURCU

Gazi University, Department of Oral and Maxillofacial

Surgery, Ankara - Turkey

e-mail: kaanhamurcu@gmail.com

Phone: +90 5054470609

\section{SUMMARY}

Purpose: To evaluate the relationships among demographic factors, pain levels, dental anxiety, coping methods, and pain perception in adult patients.

Material and Methods: A total of 150 randomly selected adult patients completed a survey, which was divided into five parts. The first part covered demographic features and patient history; the second part covered details regarding orofacial pain; the third part included the visual analogue scale (VAS) for pain determination; the fourth part included the Modified Dental Anxiety Scale (MDAS); and the fifth part included the COPE inventory to evaluate patient coping methods. The survey data were analyzed using t-tests or MannWhitney U-tests and one-way analysis of variance (ANOVA), as appropriate. Chi-square tests were used for table analyses. Results: The results revealed that coping methods differed according to gender, marital status, anxiety, and pain levels. According to results of our study, "Use of Instrumental Social Support" (3.0739), "Positive reinterpretation and growth" (3.0706) and "Active Coping" (3.0556) methods are most commonly used coping methods, respectively. While "mental disengagement" (t: 2.3039, $\mathrm{p}<0.05)$ and "use of emotional social support" (t: 2.3657, $\mathrm{p}<0.05)$ were higher for women, "drug use" (t: 2.2170, $\mathrm{p}<0.05)$ was higher for men. Anxiety levels were higher in women (W:14.48 - M:11.43, t: 4.041, $\mathrm{p}<0.05$ ) and patients with severe pain; there were no correlations between anxiety levels and any of the other assessed factors.

Conclusions: Pain perception and dental anxiety are multi-factorial problems. Several internal and external factors can affect an individual's strategies to cope with dental anxiety and pain. According to the results of this study, the methods of coping with pain are influenced by several factors such as gender, age, marital status, anxiety level, as well as pain location, severity, and duration.

Keywords: Pain Perception, Dental Anxiety, Demography, Adaptation, Psychological Factors

\section{ÖZET}

Amaç: Bu çalışmada erişkin hastaların ağrı ile başa çıkma yöntemi tercihin üzerine demografik faktörlerin, ağrı düzeyinin, dental anksiyetenin etkilerinin değerlendirilmesi amaçlanmıştır.

Gereç ve Yöntem: Rastgele seçilen 150 erişkin hastadan, beş parçadan oluşan bir anketi doldurması istenmiştir. Birinci bölüm demografik özellikleri ve hasta öyküsünü kapsamaktadır; ikinci bölüm orofasiyal ağrı ile ilgili detayları kapsar; üçüncü bölüm ağrı tespiti için görsel analog skala (VAS)'da oluşmaktadır; dördüncü bölüm Modifiye Dental Anksiyete Ölçeği (MDAS); beşinci bölüm ise hastanın ağrı ile baş etme yöntemlerini değerlendirmek için COPE envanteri içermektedir. Anket verileri, t-testi veya Mann-Whitney U-testi ve tek yönlü varyans analizi (ANOVA) kullanılarak analiz edilmiştir. Tablo analizleri 
için ki-kare testleri kullanılmıştır.

Bulgular: Başa çıkma yöntemlerinin cinsiyet, medeni durum, kaygı ve ağrı düzeylerine göre farklılaştığı ortaya konmuştur. Çalışmamızın sonuçlarına göre sırasıyla en sık kullanılan başa çıkma yöntemleri " Yararlı sosyal destek kullanımı" $(3,0739)$, " Pozitif yeniden yorumlama ve gelişme" $(3,0706)$ ve "Aktif Başa Çıkma" $(3,0556)$ yöntemleridir. Kadınlarda "Zihinsel boş verme" (t: 2,3039, $\mathrm{p}<0,05)$ ve "Duygusal sosyal destek kullanılması" (t: 2,3657, $p<0,05)$, erkekler için ise "Madde kullanımı" $(t: 2,2170, p<0.05)$ anlamlı olarak daha yüksekttir. Anksiyete düzeyleri kadınlarda (K:14,48 - E:11,43, t: 4,041, $p<0,05$ ) ve şiddetli ağrılı hastalarda daha yüksek bulunurken; anksiyete düzeyleri ile diğer değerlendirilen faktörler arasında bir korelasyon bulunamamıştır.

Sonuç: Ağrı algılaması ve dişhekimleri kaygısı çok faktöre bağlı bir problemdir. Birçok iç ve dış faktör, dental anksiyete ve bireyin ağrı ile başa çıkma yöntemleri tercihini etkileyebilir. Bu çalışmanın sonuçlarına göre, ağrı ile başa çıkma yöntemleri, cinsiyet, yaş, medeni hal, kaygı düzeyi, ağrı konumu, şiddeti ve süresi gibi çeşitli faktörlerden etkilenmektedir.

Anahtar Sözcükler: Ağrı Algılama, Dental Anksiyete, Demografi, Uyum, Psikolojik Faktörler

\section{INTRODUCTION}

The International Association for the Study of Pain defines pain as an unpleasant sensory and emotional experience associated with actual or potential tissue damage, or described in terms of such damage. ${ }^{1}$ Anxiety is defined as a condition that is accompanied by somatic symptoms, including abnormal or irrational worry and fear. An individual who lives with anxiety constantly feels that something untoward is about to happen and remains unnecessarily worried or fearful without any reason. Fear and anxiety are two different conditions, although the two terms are often used interchangeably. Fear is a reaction to known dangers. However, anxiety is a form of fear for more general and unknowable situations. Anxious individuals often cannot accept a solution for problems, even if they are experiencing health issues or pain. ${ }^{2-4}$

Health problems that do not allow individuals to perform mental, physical, and social functions result in the development of coping methods based on the individual's culture and moral values. ${ }^{5}$ Coping can be described as expending conscious effort to solve personal and interpersonal problems, and seeking to master, minimize, or tolerate stress or conflicts. ${ }^{6}$ Coping methods can differ according to several factors such as age, gender, culture, and illness, and are specific for individual cases. Clinicians are also responsible for helping patients cope with fear and anxiety.

The aim of the present study was to evaluate the relati- onships among demographic factors, pain levels, dental anxiety, coping methods, and pain perception in adult patients. The first null hypothesis of this study is that personal factors such as demographic features and dental anxiety levels will influence the selection of pain coping methods. The second null hypothesis of this study is that the location, duration, type, and severity of pain will not affect the method of coping with pain, because adults have already gained certain coping strategies due to past life experiences and characteristics.

\section{MATERIALS AND METHODS}

This project has been reviewed and approved by the Gazi University non-interventional clinical research ethics board (27/02/2013-49). Following ethics committee approval, patients who were admitted to the Department of Oral and Maxillofacial Surgery, Faculty of Dentistry of Gazi University between December-2012 / June-2013 were evaluated and 150 patients between 18 and 55 years old were randomly selected. Patients $>18$ years of age, educated, able to understand the scale factor in the survey form, and able to complete the survey without assistance were included in the present study. Patients who are younger than 18 years of age, who are illiterate or have mental disability, have not experienced a painful complaint, or do not want to be involved in this study with their own consent are excluded from the study. All patients who volunteered to participate were provided with information about the contents and aims of the survey, following which their approval was obtained.

All patients were required to complete a survey comprising five different parts. The first part included personal questions regarding gender, age, education level, marital status, and health problems. The second part included questions related to the location, time of onset, localization and spread, type, and duration of pain, as well as factors that increased and decreased the pain severity. The third part included the visual analogue scale (VAS) to determine the severity of pain. We considered a VAS score of $<5$ to represent low-intensity pain and a score of $\geq 5$ to represent high-intensity pain. The fourth part included the Modified Dental Anxiety Scale (MDAS), which is commonly used to measure the anxiety levels of patients in dental clinics. The fifth part included the COPE inventory, which is a 60 -item self-reported questionnaire with 15 scales. The overall points gained from the 15 scales enables determination of the coping method most commonly used by the individual.

MDAS, which was used in this study, is the most commonly used scale for determining anxiety levels in dental clinics. It does not include many questions and is practical for routine use in the clinic. Furthermore, it has been reported to be valid and safe for the Turkish population 
by Tunc ${ }^{8}$ and Ilguy. ${ }^{9}$ Agargun et al. ${ }^{10}$ demonstrate that the psychometric properties of COPE are a reliable measure of evaluation of coping attitudes in the Turkish sample, according to the results of the study they performed.

Statistical analysis

Numerical values are expressed as an average/standard deviation, median/min-max, and percentage. All statistical analyses were performed using SPSS 21.0 (IBM, Somers, NY, USA). The Shapiro-Wilk and Kolmogorov-Smirnov tests were used for normality testing. An independent samples t-test was used for groups showing normal dispersion and the Mann-Whitney $U$ (MWU) test was used for groups that did not show normal dispersion. The chi-square test was used for table analyses; the error level was $\alpha=0.05$.

\section{RESULTS}

The demographic characteristics of the participants are shown in Table 1, and the characteristics of pain in the participants are shown in Table 2. The severity of pain, as assessed via the VAS, is shown in Figure 1.

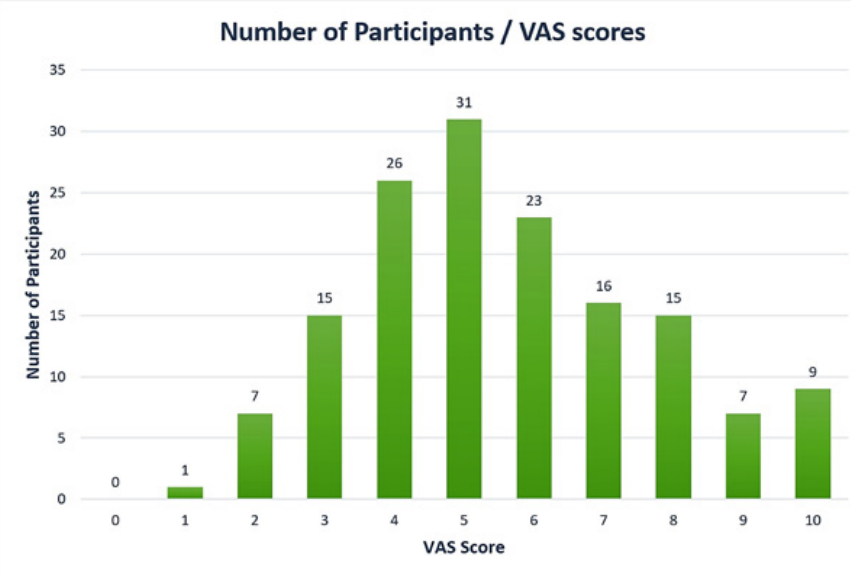

Figure 1. Pain scores on the VAS in terms of number of participants

Table 1. Demographic and social characteristic s of the participants

\begin{tabular}{lll}
\hline \multicolumn{1}{l}{$\mathbf{N}$} & $\%$ \\
\hline GENDER & & \\
\hline Female / Male & $81 / 69$ & $54 / 46$ \\
\hline AGE & $106 / 44$ & $70.7 / 29.3$ \\
\hline 18- 29 / 30 + & & \\
\hline EDUCATION LEVELS & & 4.7 \\
\hline Primary School & 7 & 5.3 \\
\hline Secondary School & 8 & 24.7 \\
\hline High School & 37 & 7.3 \\
\hline Academy & 11 & 44 \\
\hline University & 66 & 9.3 \\
\hline Master Degree & 14 & 4.7 \\
\hline Doctorate & 7 & $25.3 / 74.7$ \\
\hline MARITAL STATUS & & \\
\hline Married / Single & $38 / 112$ & \\
\hline & & \\
\hline
\end{tabular}

Table 2. Pain properties of the participants

\begin{tabular}{|c|c|c|}
\hline & $\mathbf{N}$ & $\%$ \\
\hline \multicolumn{3}{|l|}{ LOCATION OF PAIN } \\
\hline Tooth & 117 & 78 \\
\hline TMJ Area & 25 & 16.7 \\
\hline Head and Neck & 6 & 4.0 \\
\hline Lingual-Sublingual & 2 & 1.3 \\
\hline \multicolumn{3}{|l|}{ DURATION OF PAIN } \\
\hline Last 15 Days & 7 & 4.7 \\
\hline Last 1 Month & 8 & 5.3 \\
\hline Last 3 Months & 37 & 24.7 \\
\hline More Than 3 Months & 66 & 44 \\
\hline \multicolumn{3}{|c|}{ WIDE SPREADING PAIN } \\
\hline Yes & 88 & 58.7 \\
\hline No & 62 & 41.3 \\
\hline \multicolumn{3}{|l|}{ TYPE OF PAIN } \\
\hline Throbbing & 53 & 35.3 \\
\hline Electric Shock & 4 & 2.7 \\
\hline Tingling & 73 & 48.7 \\
\hline Unbearable & 20 & 13.3 \\
\hline \multicolumn{3}{|c|}{ FACTORS THAT INCREASE THE PAIN } \\
\hline Warm & 7 & 4.7 \\
\hline Cold & 8 & 5.3 \\
\hline Eating & 37 & 24.7 \\
\hline None & 66 & 44 \\
\hline \multicolumn{3}{|c|}{ FACTORS THAT DECREASE PAIN } \\
\hline Warm & 8 & 5.3 \\
\hline Cold & 11 & 7.3 \\
\hline Pain Killers & 80 & 53.3 \\
\hline None & 51 & 34.1 \\
\hline
\end{tabular}

According to the results of T-tests, the average score for the "mental disengagement" coping method was significantly higher for women than for men (t: 2.3039, $p<0.05$ ) and significantly lower for married patients than for single patients (t: $-2.073, p<0.05)$. The average score for the "use of emotional social support" strategy was significantly higher for women (t: 2.3657, $\mathrm{p}<0.05)$. Regarding the "drug use" strategy, the average score was significantly lower for women ( $\mathrm{t}:-2.2170, \mathrm{p}<0.05)$ and for married patients ( $\mathrm{t}$ : $-2.359, p<0.05)$. Regarding the "turning to religion" strategy, the average score was significantly higher for married patients (t: 2.074, $\mathrm{p}<0.05$ ) and for patients with spreading pain than for patients with localized pain (t: $3.13, p<0.05$ ). Regarding the "suppression of competing activities" strategy, the average score was significantly higher for married patients than for single patients $(\mathrm{t}: 2.253, \mathrm{p}<0.05)$. The average MDAS score was 14.48 for women and 11.43 for men, with a significant difference between the two genders (t: 4.041, $\mathrm{p}<0.05$ ). There was no significant difference in the average MDAS score between married (12.89) and single patients (13.46; t: $-0,600, p>0.05)$. Additionally, the average MDAS score for patients with spreading pain (13.42) and localized pain (12.61) showed no significant difference (t: 0.9888, $p>0.05$ ).

According to the ANOVA results, the average scores for the 
"positive reinterpretation and growth" strategy were 3.04, 3.35, and 2.66 for patients with dental pain, temporomandibular joint (TMJ) pain, and pain in the head and neck region, respectively; the average score was significantly higher for patients with TMJ (F: $4.780, p<0.05)$. The corresponding average MDAS scores were 13.11, 12.80, and 13.75, respectively, with no significant difference among the three groups ( $F: 0.115, p>0.05)$. The average scores for the "focus on and venting of emotions" coping strategy were $2.85,2.56,2.35$, and 2.46 for patients with pain after 15 days, 1 month, 3 months, and $>3$ months, respectively; the score was significantly higher for patients with pain after 15 days ( $\mathrm{F}: 3.5102, \mathrm{p}<0.05)$. The corresponding average MDAS scores were $13.48,13.03,12.50$, and 11.96 , with no significant difference (F: 0.6392, $\mathrm{p}>0.05)$. The average scores for the "mental disengagement" strategy were $2.35,2.06,2.41$, and 2.80 for patients with throbbing pain, electric shock-like pain, tingling pain, and unendurable pain, respectively; the score was significantly higher for patients with unendurable pain ( $F: 3.2544, p<0.05)$. For the "restraint coping" strategy, the corresponding average scores were $2.51,1.69,2.37$, and 2.65, respectively; this score was significantly lower for patients with electric shock-like pain ( $\mathrm{F}: 3.3862, \mathrm{p}<0.05)$. The average MDAS scores of $13.13,10.50,13.17$, and 12.95 , respectively, showed no significant differences. (F: $0.3735, p>0.05$ ).

Scores for each of the 15 coping strategies were compared between groups of patients with high and low anxiety levels, according to the MDAS score. The score for the "focus on and venting of emotions" strategy (MVU $p=0.0135$ ) was significantly higher for patients with low anxiety levels, whereas that for the "behavioral disengagement" strategy (MVU $p=0,0152$ ) was higher for patients with high anxiety levels.

Scores for each of the 15 coping strategies were also compared between patients with high and low VAS scores. The scores for the "turning to religion" (MVU $p=0.02$ ) and "using emotional social support" (MVU $p=0.01$ ) strategies were significantly higher for patients with a high VAS score. There was no relationship between MDAS scores and VAS variants (chi-square test, $0.054 ; p=0.816$ ). The average score for active coping was 3.00 for patients aged $18-29$ years and 3.24 for patients aged $\geq 30$ years. The score was significantly lower for patients aged 18-29 years (t: 1734.50, $p<0.05$ ). The score for the "turning to religion" strategy was 3.00 for patients aged 18-29 years and 3.50 for patients aged $\geq 30$ years. This score was significantly lower for patients aged 18-29 years (t: 1811.00;50, $\mathrm{p}<0.05)$.

The proportions of patients with low-intensity pain in the 18-29-years and $\geq 30$-years age group were $73.5 \%$ and $26.5 \%$, respectively, while those of patients with high-intensity pain were $69.3 \%$ and $30.7 \%$, respectively.
There was no correlation between age and VAS variants (chi-square test, $0.276 ; p=0.559$ ).

The proportions of patients with high and low anxiety levels were $80.8 \%$ and $68.5 \%$, respectively, in the $18-29$-years age group and $19.2 \%$ and $30.7 \%$, respectively, in the $\geq 30$-years age group. There was no correlation between age and MDAS variants (chi-square test, 1.549; $p=0.213$ ). The most commonly used coping strategies by the patients are listed in Figure 2.

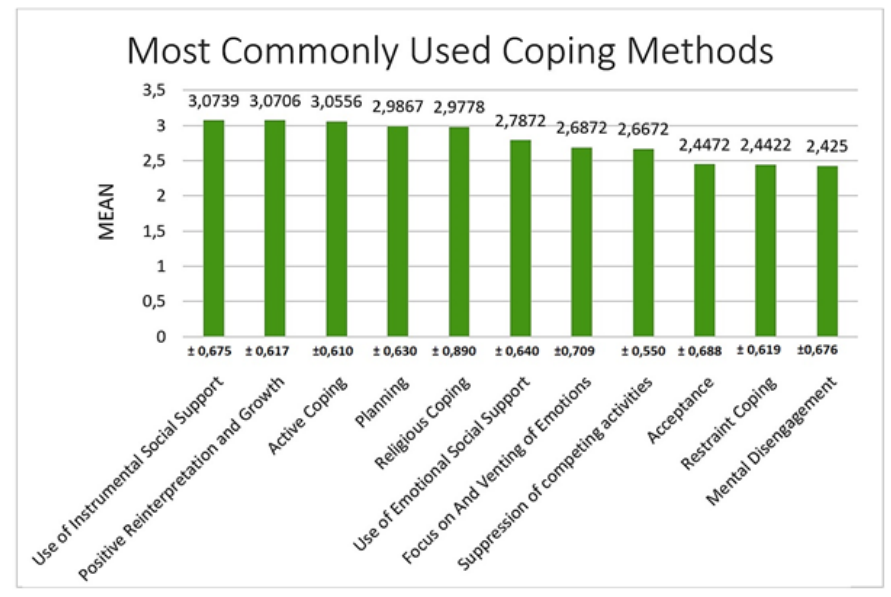

Figure 2. Most commonly used coping methods

\section{DISCUSSION}

In this study, we evaluated the relationships among demographic factors, pain levels, dental anxiety, coping methods, and pain perception using a five-part survey in adult patients complaining of pain. According to the results of this study, the first null hypothesis was confirmed, while the second hypothesis failed. The results revealed that tendency to the coping methods affected both demographic features and characteristics of pain.

Bedi and McGrath ${ }^{11}$ reported that dental anxiety is affected by factors such as age, gender, education level, sociodemographic factors, oral health status, frequency of dental visits, past treatment experience, and type and duration of dental treatment. Studies reporting the relationship between age and anxiety levels have documented varied results. According to Milgrom et al., ${ }^{12}$ dental anxiety decreases with age. Hakeberg ${ }^{13}$ found that patients aged 20-39 years exhibited higher anxiety levels compared with younger and older age groups. Kunzelmann and Dunninger ${ }^{14}$ reported that the level of fear reaches a plateau after a certain age, probably because the fear associated with dental issues loses importance with an increase in other health problems. Hofer et al. ${ }^{15}$ reported that individuals with high anxiety levels were significantly younger. Two Finnish studies also showed that the proportion of individuals who were very scared or slightly scared to visit a dentist was higher in younger age groups. ${ }^{4,16}$ In addition, an older study by Corah ${ }^{17}$ found higher dental anxiety scores in younger subjects. Ragnarsson ${ }^{18}$ reported that 
there is no relationship between age and dental anxiety. In the present study, we found no significant correlation between age and anxiety. However, while the "drug use" strategy was more common in 18-29-year-old individuals, individuals aged $\geq 30$ years preferred more problem-focused methods. Moreover, individuals with low anxiety levels preferred more effective coping methods such as "focus on and venting of emotions," whereas those with high anxiety levels showed an inclination towards "behavioral disengagement."

In our study, the strongest indicator of dental care behavior was gender. It is known that women report higher levels of fear more frequently and comfortably. Several studies have indicated that dental fear is more prevalent among women, whereas some studies report that there are no gender-related differences in dental fear ${ }^{19-23}$. Ter Horst and De Wit ${ }^{24}$ reported that, universally, women are more anxious. According to Stouthard and Hoogstraten, ${ }^{25}$ high anxiety levels in women originate from their externalization of fear more easily compared to men. In the present study, although anxiety levels were significantly higher in women, there was no significant correlation between gender and severity of pain. Regarding coping strategies, women preferred strategies such as "mental disengagement" and "use of emotional social support," whereas men preferred passive strategies such as "drug use."

Hallstrom and Halling ${ }^{26}$ reported that dental anxiety is higher in individuals with low education levels. Stabholz and Peretz ${ }^{27}$ assessed the correlation between education level and anxiety and reported that educated individuals exhibited better coping skills in stressful situations. llguy et al. ${ }^{9}$ could not find any association between dental anxiety and education level. Similarly, in the present study, there was no significant difference between anxiety and education level.

We found that the average score for "mental disengagement" was significantly lower for married patients, and they more often preferred strategies such as "turning to religion" and "suppression of competing activities," while single patients preferred "mental disengagement" and "drug use."

Praying to a God or a higher power is a worldwide practice, regardless of the culture, religion, or method of offering prayers. ${ }^{3}$ Pain studies suggest that coping strategies involving praying are more frequently preferred by individuals who feel less powerful, are more depressed, and have higher levels of fear. ${ }^{22,}{ }^{28}$ In the present study, individuals with more severe pain more frequently chose the "turning to religion" and "use of emotional social support" strategies. In addition, anxiety levels were higher in patients with severe pain. Accordingly, we can conclude that patients who preferred these coping methods are highly anxious patients. This result is significant, becau- se severe pain can psychologically pressurize patients. Some pain studies showed that praying as a passive method of coping represented somewhat unrealistic hopes and desires, and was associated with lower self-effica$\mathrm{cy}^{22,29}$ while Loggia et al. ${ }^{30}$ reported that positive spiritual thoughts decrease dento-alveolar pain, while negative thoughts increase pain perception.

According to Haythornthwaite and Benrud-Larson, ${ }^{31}$ emotional situations are associated with pain from chronic illnesses. Similarly, Krittayaphong et al. ${ }^{32}$ reported that angina pain was experienced more often by cardiac patients with depression. Villemure and Bushnell ${ }^{33}$ reported that similar situations are valid for acute dental pain, and that preoperative anxiety is associated with postoperative pain. They showed that situations positively affecting the soul, such as good music, decrease the perception of pain, whereas anxiety and some personal characteristics increase the perception of pain. The results of the present study indicated that anxiety increases pain levels.

In the present study, patients who visited our clinic with pain in the last 15 days more frequently used the "focus on and venting of emotions" coping strategy, while there was no significant difference between anxiety levels and the duration of pain. Furthermore, there was no relationship between the pain location and type and anxiety levels. Individuals with spreading pain preferred the "turning to religion" strategy, while patients with TMJ pain preferred "positive reinterpretation and growth."

The most commonly used coping strategies in our study included "use of instrumental social support" (3.074 \pm 0.675$)$, "positive reinterpretation and growth" (3.071 \pm 0.617$)$, and "active coping" (3.056 \pm 0.611$)$, while the less frequently used strategies include "humor," "denial," "behavioral disengagement," and "drug usage," which are emotion-focused and avoidant.

This study is limited by the small sample size, which may limit generalization of the results. Future studies with a larger number of participants are needed to confirm the results of this study. In addition, similar studies in different cultures and nationalities will allow for global assessment of the results. The strength of this study is the evaluation of several variables and detailed comparisons of several factors using a survey including different assessment tools.

\section{CONCLUSIONS}

According to the results obtained within the limits of this study, the ways of coping with pain are influenced by many factors such as patient gender, age, marital status, anxiety level, pain zone, severity, and duration. The identified differences are as follows:

-While "mental disengagement" and "use of emotional social support" were higher for women, "drug use" was 
higher for men.

-While "mental disengagement" and "drug use" were higher for single patients, "turning to religion" and "suppression of competing activities" were higher for married patients.

-Patients with low anxiety preferred "focus on and venting of emotions" and patients with high anxiety preferred "behavioral disengagement."

-Active coping methods and "turning to religion" were lower for patients aged 18-29 years

."Turning to religion" was higher for spreading pain, "positive reinterpretation and growth" was higher for patients with TMJ pain, "mental disengagement" was higher for patients with unendurable pain and, "restraint coping" lower for patients with electric shock-like pain

-"Focus on and venting of emotions" was higher for patients with pain in the past 15 days.

."Turning to religion" and "using emotional social support" were significantly higher for patients with high VAS score.

-Anxiety levels were higher in women and patients with severe pain; there was no correlation between anxiety levels and any of the other assessed factors.

. "Use of instrumental social support," "positive reinterpretation and growth," and "active coping" methods were the most preferred methods of coping.

Conflicts of interest statement: "None declared."

Acknowledgement: We thank Eda Gizem Koçyiğit for assistance with the statistical analysis of our study. We would also like to show our gratitude to Prof. Berrin Işık for sharing her pearls of wisdom with us during the course of this research.

\section{REFERENCES}

1.IASP. Part III: Pain Terms, A Current List with Definitions and Notes on Usage. In: Merskey $H$, Bogduk N, editors. Classification of Chronic Pain 2ed. Seattle USA: IASP Press; 1994 (Updated in 2014). p. 209-14.

2.Bernson JM, Elfstrom ML, Hakeberg M. Dental coping strategies, general anxiety, and depression among adult patients with dental anxiety but with different dental-attendance patterns. Eur J Oral Sci. 2013;121:270-6.

3.Freeman RE. Dental anxiety: a multifactorial aetiology. Br Dent J. 1985; 159:406-8.

4.Pohjola V, Lahti S, Vehkalahti MM, Tolvanen M, Hausen $\mathrm{H}$. Association between dental fear and dental attendance among adults in Finland. Acta Odontol Scand. 2007;65:224-30.

5.Ostell A. Coping, problem solving and stress: a framework for intervention strategies. $\mathrm{Br} \mathrm{J}$ Med Psychol. 1991;64 ( Pt 1):11-24.

6.Folkman S, Lazarus RS, Gruen RJ, DeLongis A. Apprai- sal, coping, health status, and psychological symptoms. J Pers Soc Psychol. 1986;50:571-9.

7.Holahan CJ, Moos RH. Personal and contextual determinants of coping strategies. J Pers Soc Psychol. 1987;52:946-55.

8.Tunc EP, Firat D, Onur OD, Sar V. Reliability and validity of the Modified Dental Anxiety Scale (MDAS) in a Turkish population. Community Dent Oral Epidemiol. 2005;33:35762.

9.Ilguy D, Ilguy M, Dincer S, Bayirli G. Reliability and validity of the Modified Dental Anxiety Scale in Turkish patients. J Int Med Res. 2005;33:252-9.

10.Agargun MY, Besiroglu L, Kiran UK, Ozer OA, Kara $\mathrm{H}$. COPE (Başa Çıkma Tutumlarını Değerlendirme Ölçeği): Psikometrik özelliklere ilişkin bir ön çalışma. Anadolu Psikiyatri Dergisi. 2005;6:221-6. [Turkish]

11.Bedi R, McGrath C. Factors associated with dental anxiety among older people in Britain. Gerodontology. 2000;17:97-103.

12.Milgrom $P$, Fiset $L$, Melnick $S$, Weinstein P. The prevalence and practice management consequences of dental fear in a major US city. J Am Dent Assoc. 1988;116:641-7.

13. Hakeberg $M$, Berggren U, Grondahl HG. A radiographic study of dental health in adult patients with dental anxiety. Community Dent Oral Epidemiol. 1993;21:27-30.

14. Kunzelmann $\mathrm{KH}$, Dunninger $\mathrm{P}$. [The patient--his anxiety and his assessment of the dentist as variables in the compliance model]. Dtsch Zahnarztl Z. 1989;44:3569.

15. Hofer D, Thoma MV, Schmidlin PR, Attin T, Ehlert U, Nater UM. Pre-treatment anxiety in a dental hygiene recall population: a cross-sectional pilot study. BMC Oral Health. 2016;16:43.

16. Lahti S, Vehkalahti MM, Nordblad A, Hausen H. Dental fear among population aged 30 years and older in Finland. Acta Odontol Scand. 2007;65:97-102.

17.Corah NL. Development of a dental anxiety scale. J Dent Res. 1969;48:596.

18. Ragnarsson E. Dental fear and anxiety in an adult Icelandic population. Acta Odontol Scand. 1998;56:100-4.

19.Abrahamsson $\mathrm{KH}$, Berggren U, Hallberg L, Carlsson SG. Dental phobic patients' view of dental anxiety and experiences in dental care: a qualitative study. Scand $J$ Caring Sci. 2002;16:188-96.

20.Bernson JM, Hallberg LR, Elfstrom ML, Hakeberg M. 'Making dental care possible: a mutual affair': a grounded theory relating to adult patients with dental fear and regular dental treatment. Eur J Oral Sci. 2011;119:373-80.

21. Heft MW, Meng X, Bradley MM, Lang PJ. Gender differences in reported dental fear and fear of dental pain. Community Dent Oral Epidemiol. 2007;35:421-8.

22. Holtzman JM, Berg RG, Mann J, Berkey DB. The relationship of age and gender to fear and anxiety in response 
to dental care. Spec Care Dentist. 1997;17:82-7.

23.Skaret E, Raadal M, Kvale G, Berg E. Gender-based differences in factors related to non-utilization of dental care in young Norwegians. A longitudinal study. Eur J Oral Sci. 2003;111:377-82.

24.ter Horst G, de Wit CA. Review of behavioural research in dentistry 1987-1992: dental anxiety, dentist-patient relationship, compliance and dental attendance. Int Dent J. 1993;43:265-78.

25.Stouthard ME, Hoogstraten J. Prevalence of dental anxiety in The Netherlands. Community Dent Oral Epidemiol. 1990;18:139-42.

26. Hallstrom T, Halling A. Prevalence of dentistry phobia and its relation to missing teeth, alveolar bone loss and dental care habits in an urban community sample. Acta Psychiatr Scand. 1984;70:438-46.

27.Stabholz A, Peretz B. Dental anxiety among patients prior to different dental treatments. Int Dent J. 1999;49:904.

28. Moore R, Birn H, Kirkegaard E, Brodsgaard I, Scheutz F. Prevalence and characteristics of dental anxiety in Danish adults. Community Dent Oral Epidemiol. 1993;21:292-6.

29. Hakeberg M, Berggren U, Carlsson SG. A 10-year follow-up of patients treated for dental fear. Scand $\mathrm{J}$ Dent Res. 1990;98:53-9.

30.Loggia ML, Schweinhardt P, Villemure C, Bushnell MC. Effects of psychological state on pain perception in the dental environment. J Can Dent Assoc. 2008;74:6516.

31. Haythornthwaite JA, Benrud-Larson LM. Psychological aspects of neuropathic pain. Clin J Pain. 2000;16:S1015 .

32. Krittayaphong R, Light KC, Golden RN, Finkel JB, Sheps DS. Relationship among depression scores, beta-endorphin, and angina pectoris during exercise in patients with coronary artery disease. Clin J Pain. 1996;12:126-33.

33.Villemure C, Bushnell MC. Cognitive modulation of pain: how do attention and emotion influence pain processing? Pain. 2002;95:195-9. 